\title{
Impact of Desertification on Livelihoods in Katsina State, Nigeria
}

\author{
Bishir Gambo Saulawa \\ Julius Atlhopheng \\ Michael Bernard Kwesi Darkoh \\ Bothepha Mosetlhi \\ Department of Environmental Science \\ University of Botswana \\ Gaborone
}

\section{Desertification}

Is one of the overwhelming environmental problems in Katsina State where 75\% of its nearly 6 million people on a 24,192 km2 of land depend on agriculture. Few studies have been undertaken to enhance the state of knowledge of the consequences of desertification in this area. As a result, anecdotal data has been relied upon in making an assessment and often policy formulations. It was against this background that the study sought to assess the perceived impact of desertification on livelihoods in Katsina State. A total of 385 randomly selected farming families from across the three agro-ecological zones of Katsina State and 29 key informants were interviewed on the impact of desertification on livelihoods in the State. The data obtained were analysed using frequencies, logistic regression and Chi-square as well as contextual analysis.The study established that the impact of desertification on livelihoods included major effects on pastoralism and rain-fed crop production through degradation of pastoral areas and reduction in crop yields. Desertification also amplified conflicts between the farming families and the Fulani herders. Desertification was further revealed to have influenced migration to urban centres and accelerated out-migration to other countries. As a result of desertification, forest reserves have diminished through deforestation and conversion to farmlands by the farming families. Desertification has also promoted bush encroachment and the disappearance of palatable grass species. Contrary to the generalized views, the loss of farmland, abandoned settlements and dried up wells were found to be uncommon in the study area. The result of this study concretizes the central statement of the study that impact of desertification is sitespecific, and each location requires its independent analysis before a conclusion canbe reached.

Keywords: Desertification, Farming families, Impact, livelihoods, Agro-ecological zones

\section{Introduction}

The $21^{\text {st }}$ century has witnessed an unprecedented attention to the indisputable concerns of environmental resources management, protection and sustainability (UNEP, 2012). The focus has been in an environment that allows the human use of resources judiciously without jeopardizing the ability of future generations to use them (WCED, 1987). Thus, the recognition prompted inquiries (e.g. Mooney \&Darkwa, 2014; Loxton et al., 2014; Orr et al., 2009 and Foster et al., 2003) into resource use consequences and possible measures to check any injudicious applications of natural resources. However, concerns have been directed to a phenomenon that has shaped the quality, generation and enhancement of land under the influence of climatic factors and human activities. The phenomenon, universally called "desertification," is defined as land degradation in arid, semi-arid and dry sub-humid zones, resulting from various factors, including climatic variations and human activities (UNCCD, 1994). It has received and continues to receive much attention (Baartman et al., 2007). It ranks among the greatest contemporary environmental problems (MA, 2005; Abdi et al., 2013), a critical social and economic issue (Grainger 2009; Vogt et al., 2011) and perhaps the most important environmental issue (Houerou, 1996; Dregne, 1996; Kasas, 1995 and Reynolds 2001) in the $21^{\text {st }}$ Century (Sokona et al., 2007). The global concern started in earnest in 1977, when the United Nations Conference on Desertification (UNCOD) convened in Kenya and came up with the United Nations Plan of Action (PACD). 
It was formalized in 1992 at the United Nations Conference on Environment and Development (UNCED) in Rio de Janeiro with the development of a Convention to Combat Desertification in those countries experiencing drought and/or desertification particularly in Africa (Reynolds \& Stanford-Smith, 2001; FGN, 2012). Since then, scientific research on land has focused on desertification studies, yet the link between science and policy makers appears to be weak, and information flow among stakeholders involved in the combat against land degradation and desertification is not moving fast either (Zdruli et al., 2010).

However, the causes and consequences of desertification cannot be generalized on a global, continental, regional or national level. They are site specific (Hellden, 2003). Because of site specificity, it presupposes that the impact of desertification on livelihoods cannot be generalized. The concerns on desertification have also given insufficient attention to people's adaptive response (Tiffen \& Mortimore, 2002). It is clear that when thresholds are crossed, the human environment system will move into a new state (Grainger, 2009). The effect of any form of destabilization of the environment has always been intolerable and vicious. Thus, the generic impacts can be understood within the limits of causation of phenomenon, but the diagnosis can be better appreciated and applied based on the specific site or location. The Millennium Ecosystem Assessment (2005) emphasized that the magnitude and impact of desertification vary widely from place to place and change over time. The variability is driven by the degree of aridity combined with the pressure people put on the ecosystems. There is, however, a wide gap in our understanding and observation of desertification and its underlying factors (MA, 2005). Thus, FAO (1993) views the consequences of desertification as dependent on four factors that vary by region, country and year:

- The seriousness and extent of land degradation;

- The severity of climatic conditions;

- The number and diversity of affected population; and

- The level of development of the country involved.

Consequently, the poorer the people and the less developed the countries, the more profound will be the future effects of desertification and the greater the potential for tragedy when natural conditions especially climatic become difficult. Thus, the need to identify the socio-economic impacts of desertification in the study area is crucial.Withoutaccurate data and relevant information, it is impossible to predict, adjust or strengthen actions to curtail land degradation and face the challenge of food security through sustainable agriculture and efficient water management (Sokona et al.,2007). This study has attempted to address this significant gap in knowledge of site impact specificity, for the Katsina State in Nigeria.

\section{Materials and Methods}

\section{Selected areas of study, sample population and sampling technique}

Fieldwork for this study was conducted in Katsina State from June 2015 to August 2015. Katsina State, which lies in the semi-arid region of Nigeria (Adekunle et al., 2005), is one of the Frontline States which bears the brunt of desertification significantly. Six local government areas across the three agro-ecological zones were purposively selected for the study. The extreme northern part lies within the Sahel Savannah with rainfall on average of less than $600 \mathrm{~mm}$ per year. The northern part lies within the Sudan Savannah with the rainfall average of about $800 \mathrm{~mm}$ per year and the southern part in the Guinea Savannah with rainfall averages of $1000 \mathrm{~mm}$ per annum. This variability in rainfall distribution made the selection from the different agro-ecological zones imperative which gave a broader scope of the investigation and reduced bias.

Four categories of respondents were involved in the study, drawn from the sampled local government areas. The first group constituted the farming families, the second group of Block Extension Supervisors (BES) and the third group the senior Government officials. Additionally, three community leaders were selected from each of the sampled local government. The primary focus included farming families from the six local government areas because according to Bello (2014) $67 \%$ of the land in Katsina state is devoted to cultivation. Additionally, Perkins et. al (2011) observe that for land degradation assessment to be accurate and reliable, it must incorporate multiple perspectives using a variety of methods at multiple scales, including the perspectives of those who manage and/or use the land. Therefore, including the farming families since they are the major stakeholders in land issues became appropriate. 


\section{Sample size distribution}

Simple random sampling was used to select farmers from the six local government areas. Applying the Krejcie \& Morgan (1970) formula to a target population of 800,000 farming families in the study area, a total of 385 farming families were selected and interviewed. The key informant interview participants were selected purposively. These comprised five senior Government officials, six Block Extension Supervisors (BES) drawn from the sampled coterminous local government areas and 18 community leaders. As observed by Mosetlhi (2012), key informant participants by their expertise and mandates are expected to hold rich information or experiences related to the phenomenon under investigation. The selected respondents for this study were people who have knowledge and experiences of environmental issues based on their institutional mandates. They had a long-term interaction with the farmers on issues of policy implementation and introduction of new land management practices. The interviews provided an institutional as well as community leaders' perspective of the impact of desertification in the study area.

\section{Statistical analysis}

The analysis of the questionnaire responses was done using frequencies, logistic regression, Chi-square and the IBM SPSS Package. Frequency tables, column charts were used to describe the data. TheBinomial Logistic Regression was employed to see whether the response variables can be predicted from the independent variables and also to calculate explained variation. The Pearson Chi-square was employed to indicate the strength of the relationship between the dependent and the independent variables. All the 385 questionnaires were successfully retrieved. Additionally, interviews with the principal informants involving the extension workers, community leaders, and senior civil servants were conducted to elicit more information from them. The interviews were contextually analysed. Photographs were also presented for observation.

\section{Results and Discussion}

\section{Socio-economic variables of the sample population}

The majority of the heads of the farming families were below 46 years old while about $42.3 \%$ were above 46 years of age. The findings mirrored the study by Woodsong (1994) who noted that individuals in the mid-30s and 40s have a wide economic option to explore. He argued that it is during this stage that farming is likely to be combined with off-farm economic activity. About $94 \%$ of the head of the farming families were males while females accounted for 6.5\%. The findings corroborate Butterworth et.al. (2008), who argued that the low status of women in Nigeria is mainly a result of traditional gender roles that largely confines women to the domestic sphere. The majority of the farming families were mostly married (79\%) with only $6 \%$ single. The divorced head of households accounted for $11 \%$ while the widowed head of farming families accounted for $4 \%$. The results were similar to findings by Nuhu et.al (2014) in a study of barriers to women participation in Agricultural development in Bauchi, Nigeria.

The majority of the heads of farming households are literate holding a primary certificate (44\%), WASC certificate (29\%) and degree holders' $13 \%$. Over $14 \%$ of the farming families were not literate. Adekunle (2009) pointed out that the level of education of farmers will directly affect their ability to change and accept new ideas. Similar findings were revealed by Ibrahim \&Aliero (2012) on analysis of farmer's access to formal credit in the rural areas of Nigeria.

Respondents who have been in farming practice for more than 15 years constitute $65 \%$ of the sampled population; followed by those in the category of 11-15 years (28\%) and those with 6-10 years (7\%). The years of experience in agriculture plays a major role in enhancing productivity and application of conservation measures. In the absence of experience, there can be the likely outcome of low production and income for farming families. Subsistence agriculture is the main type of farming practiced by the farming families (78\%) followed by large-scale farming $(22 \%)$. Similar trends in the study area were also noted by Adekunle et. al (2005). About $55 \%$ acquired their land through inheritance, $27 \%$ through purchase and $18 \%$ by lease agreements. Tsueet. al (2014) observe that land tenure security impacts substantially on the increase in environmental sustainability. It is seen as an incentive to engage in sustainable agricultural production and consider the long-term impact of over-exploitation of the land and its resources. The main source of capital for the study population is personal savings (96\%) while only $4 \%$ utilizes commercial banks. Access to credits could have much of influence on the performance of the farming families in production and conservation practices. 


\section{Impact of Desertification on Livelihoods}

To achieve the objective of identifying the impact of desertification on livelihoods in the study area, questions were posed and answeredby respondents on the effect of desertification on the following: pastoralism, rain-fed crop production, natural resources use, migration, farmlands, human settlements, wells and water supplies, forest reserves and grazing lands.

\section{Pastoralism and desertification}

The responses to the predictor variables indicated that there is a change in livestock size as a result of desertification $(60.5 \%)$ while $39.5 \%$ of the respondents posited no change as shown in Figure 1 . The respondents were in agreement on changes and form of livestock change (69.4\% sometimes and $30.6 \%$ always). The result indicates that the farming families try to adapt to the challenges and uncertainties of pasture provisioning.

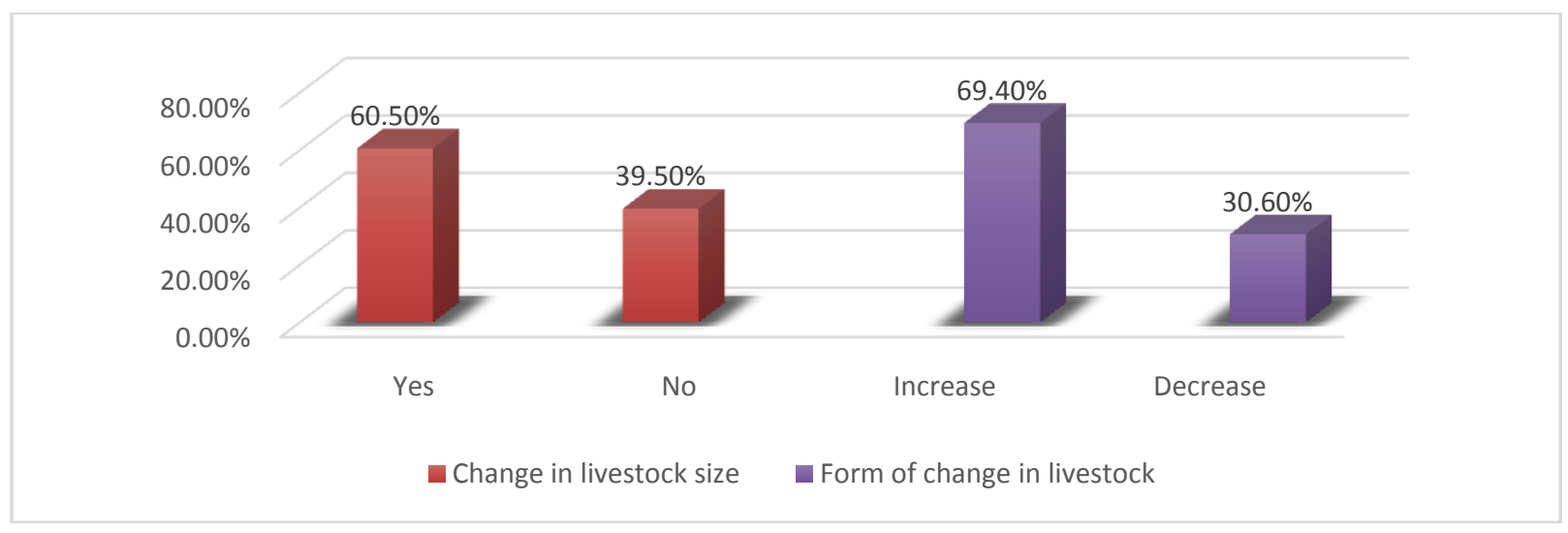

Figure 1Changes in size of livestock and form of change in livestock

Source: Field Survey (2015)

The farming families indicated that the types of livestock kept were as follows: Combined cattle, sheep and goats (54.8\%), Cattle (23.4\%) and goat $13 \%$ while sheep at $8.8 \%$ as shown in Figure 2. The combination of the bigger and smaller ruminants in the study area reveals the strategy of the farming families to reduce the health risk associated with livestock. At the same time, to the farming families, the strategyprovides an easier and quicker means to dispose of the smaller ruminants like the sheep and goats to meet the livelihood demands of their families.

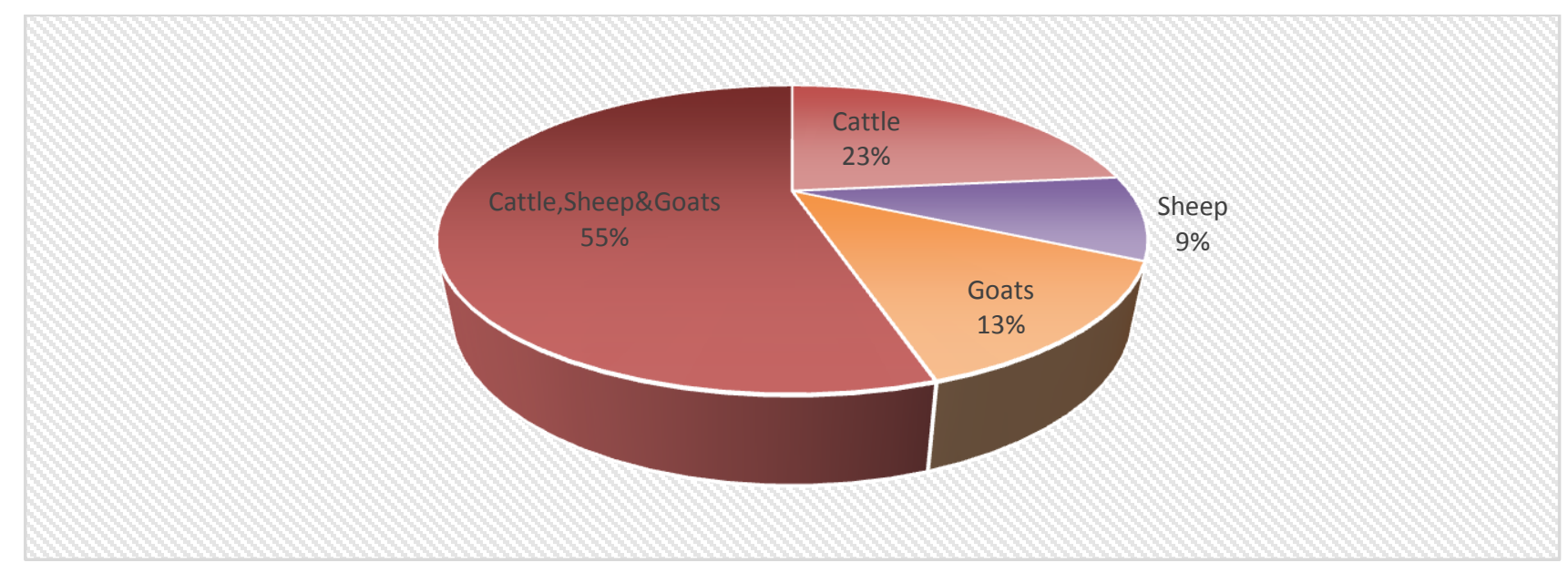

Figure 2Types of livestock kept

Source: Field Survey, 2015 
Themajority of farming families were of the opinion that as a result of desertification, the prices of livestock have declined $(41.6 \%)$ while $33.8 \%$ perceived there was an increase in livestock prices and $24.6 \%$ felt the prices had been stable as depicted in Figure 3. The overall picture portrays situations of abject poverty prevalence in the study area, as the farming families take a long time to dispose cattle for instance at the price they wished. Thus, the farming families are faced with harvests that are too small to both feed their families and fulfill their other commitments. Livestock sales act as a buffer in times of hardship, farmers disinvesting in these assets to buy food.

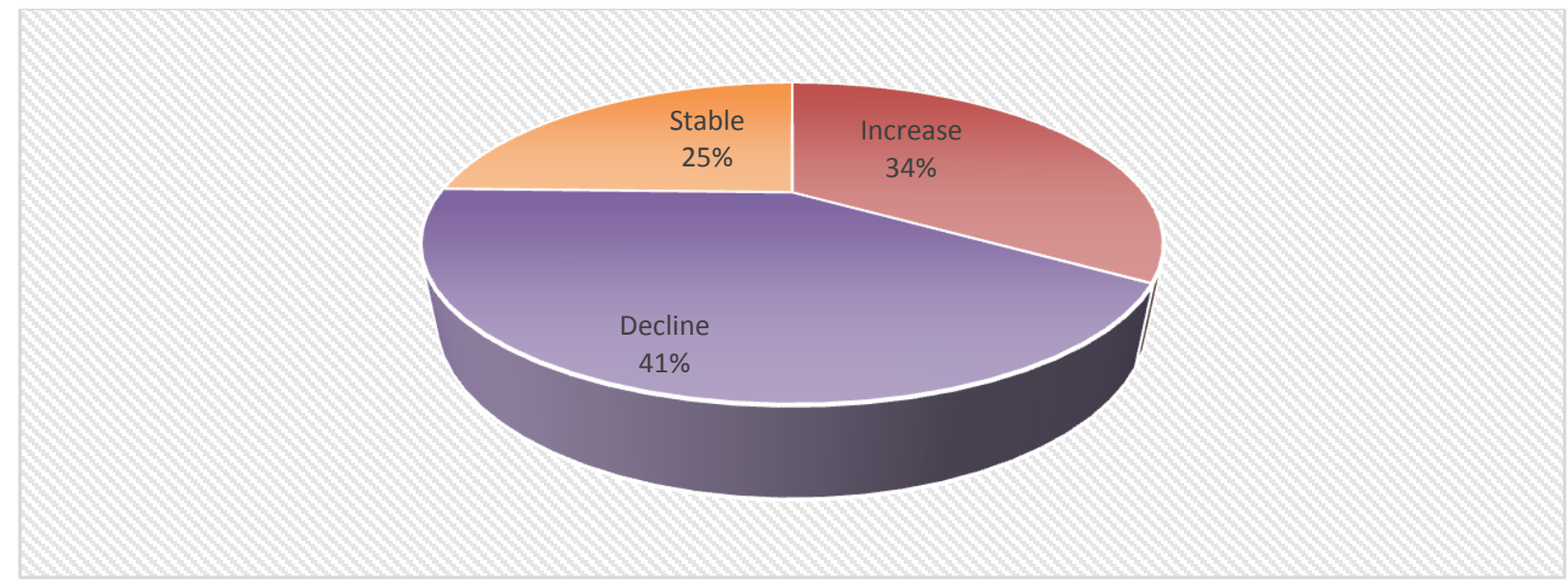

Figure 3 Prices of livestock

Source: Field Survey (2015)

There was a general consensus among the key informants in the study area that desertification has led to a price decrease of bigger livestock (cattle) and a shift to smaller livestock (sheep and goats) in the study area. Further, research in Northern Nigeria by Gbahago (2011) reached the same conclusion of a shift from large ruminants to small ruminants. This is because small ruminants have many advantages over large ruminants like cattle and camels. First, small ruminants like goats and sheep are not only less costly and more resilient, but are also easier to feed, and they reproduce faster than cattle. Similarly, it is simpler to sell small ruminants than cattle in times of hardship. Other studies have also observed such trends, e.g. Tully and Shapiro (2014) in their analysis of Kenyan livestock market and feasibility study of livestock business, Stiles (1993) on his study of desertification and land degradation in Northern Kenya and Mortimore (1989) in his study on drought, farming, famine and desertification in West Africa.

The logistic regression was employed to ascertain the relationships between market prices of livestock, change in types of livestock owned, change in livestock size and types of livestock kept. The correlation matrix (Table 1) shows the linearity of the association.

Table 1 Correlation Matrix

\begin{tabular}{|ll|l|l|l|l|l|}
\hline & & Constant & Identify & Kept & Type & Fared \\
\hline \multirow{4}{*}{ Step 1 1} & Constant & 1.000 & .000 & -.397 & .000 & .000 \\
& Identify & .000 & 1.000 & -.523 & -.372 & -.468 \\
& Kept & -.397 & -.523 & 1.000 & -.387 & .000 \\
& Type & .000 & -.372 & -.387 & 1.000 & .000 \\
& Fared & .000 & -.468 & .000 & .000 & 1.000 \\
\hline
\end{tabular}

Source: Field Survey (2015)

Further, the Omnibus Tests of Model Coefficients was applied, and the result indicates that the $\chi^{2}(4)=355.78$. The greater the chi-square statistic, the stronger the relationship between the independent and dependent variable as indicated in Table 2. 
Table 2 Omnibus Test of Model Coefficients

\begin{tabular}{|ll|l|l|l|}
\hline & & Chi-square & df & Sig. \\
\hline \multirow{3}{*}{ Step 1 } & Step & 355.778 & 4 & .000 \\
& Block & 355.778 & 4 & .000 \\
& Model & 355.778 & 4 & .000 \\
\hline
\end{tabular}

Source: Field Survey (2015)

The regression model summary in Table 3 indicates the Nagelkerke R square value as .817 which signifies that $81.7 \%$ of the variance in the form of change in types of livestock kept. It further shows that the kind of change in the livestock kept can be correctly predicted by $85.2 \%$ by the independent variables.

Table 3 Model Summary

\begin{tabular}{|l|l|l|l|}
\hline Step & -2 Log likelihood & $\begin{array}{l}\text { Cox \& Snell R } \\
\text { Square }\end{array}$ & $\begin{array}{l}\text { Nagelkerke } \\
\text { Square }\end{array}$ \\
\hline 1 & $160.776^{\mathrm{a}}$ & 603 & .817 \\
\hline
\end{tabular}

Source: Field Survey (2015)

\section{Rain-fed crop production and desertification}

The responses to the predictor variables indicated that the farming families have noticed a change in crop yields (92.2\%) while only $7.8 \%$ perceived no change in crop yields as captured in Figure 4. The respondents who had noticed changes in crop yield also scored the performance of crop yield as low as well as positively attested to the evolution in types of crops cultivated. The result shows the serious predicament the farming families faceand goes a long way to explaining an anomaly in services provided by the land. It also indicates that the farming families have noticed the problem, but little efforts were made to salvage the situation.

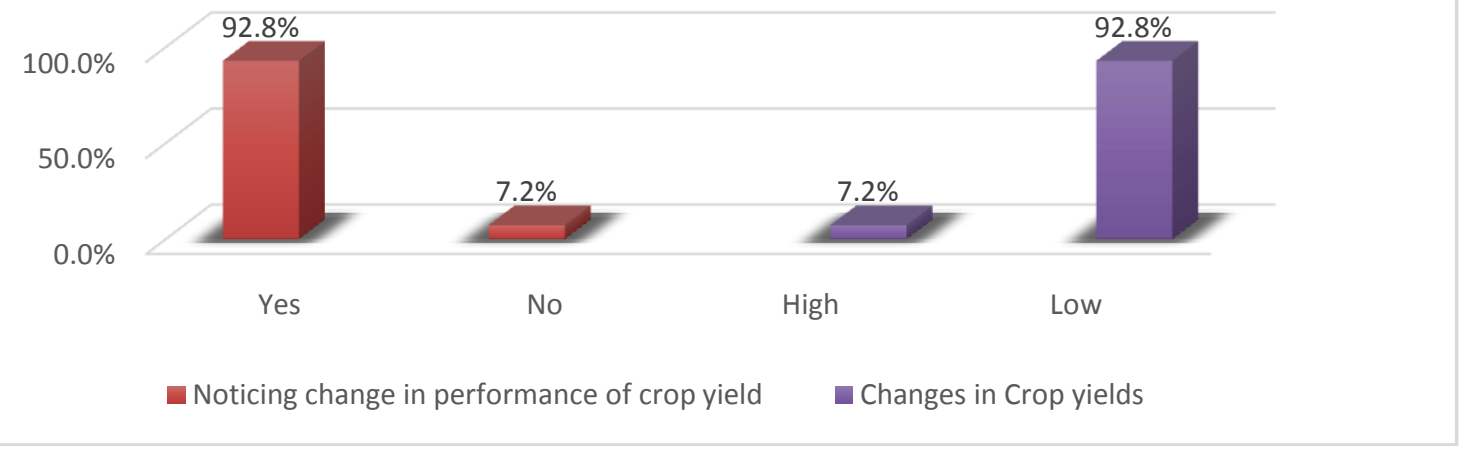

Figure 41 Influence of desertification on rainfed crop production

Source: Field Survey (2015)

The farming families further attested that the value of crop production has changed $(81.0 \%)$. Over half of the respondents $(53.8 \%)$ opined that household food production last only three months, while for $26.2 \%$ of the farming families, household food produce last only six months and only $20 \%$ of the respondent opined that the household food provisions last eight months as shown in Figure 5. The result reveals that the farming families in the study area are not food secure, which has a tendency of precipitating unrest. In the case of farming families whose food last between 3-6 months (80\%), this could be probably due to low capital to purchase inputs needed for the production of food like fertilizer. It could further imply that the majority of the farming families whose food does not last them up to six months engage in off-farm activities to get food that will sustain the family for the remaining period. UNESCO (2007) observes that the poor households that are affected by drought and desertification do not have adequate resources to deal with food shortages leading to food insecurity and hunger that affects millions of people. 
The result mirrored findings of Thelma (2015) that areas in the Sahelian region of Nigeria are the major producers of livestock and staple cereals such as millet, corn, sorghum wheat, beans, groundnut which are essentials for food security.The result agrees with the findings of the study of Olagunju (2015) on drought, desertification, and the Nigerian environment and the findings by Mortimore (1989), EL-Karouri (1986),Nneji (2013)and Stephen (2014).

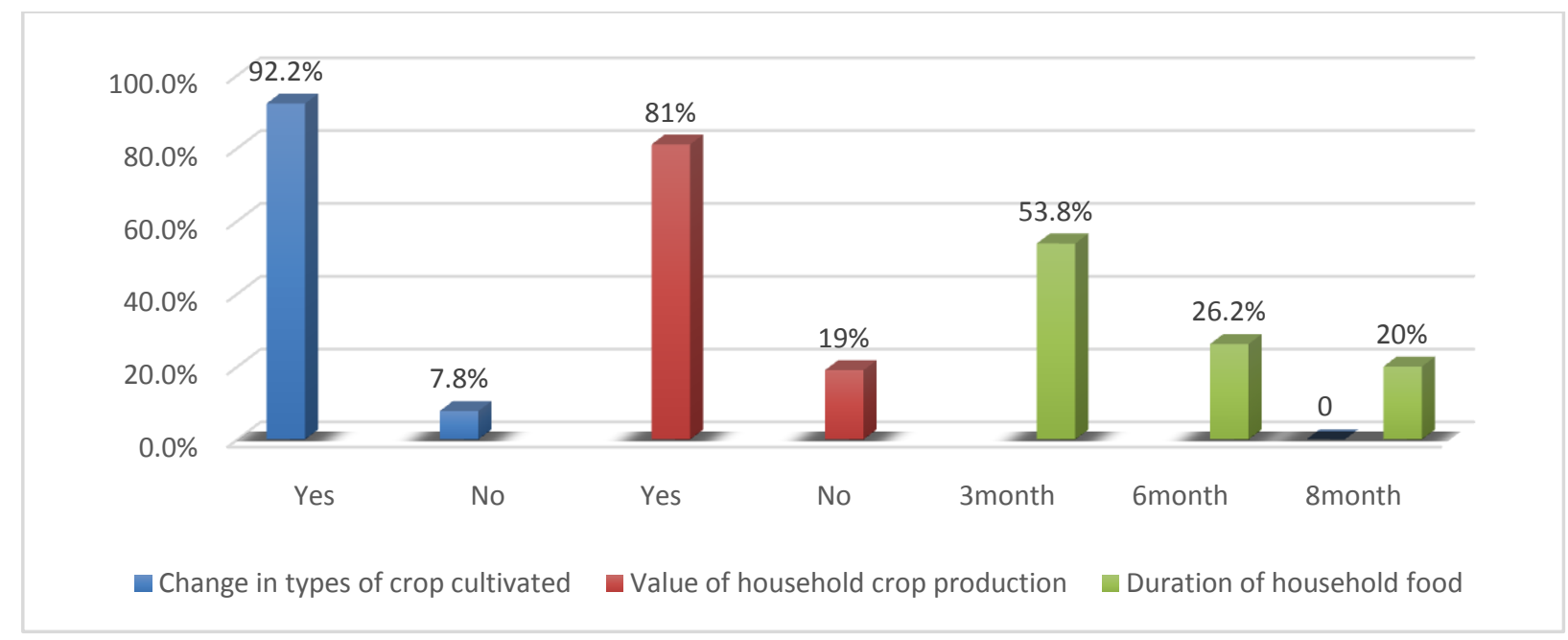

Figure 5 Effect of desertification on types of crops cultivated, value and duration of household food Source: Field Survey (2015)

Results from the questionnaire further indicated on a disaggregation basis a hundred percent response by the farming families in both the Sahel and the Sudan Savannah affirming the decline in the crop yields. About $83 \%$ of the respondents in the Northern Guinea Savannah also emphasized the crop yield decline as shown in Figure 6. Thus, it could be deduced that the crop yield in the study area decreased significantly over the years. The disaggregated results from the ecological zones indicated that farming families (86\%) in the Sahel region has food provisioning that lasts only three months with only $14 \%$ having food provisions that lasted for only six months. In the Sudan Savannah produce last three and six months as responded by b $64.8 \%$ and $35.2 \%$ of the farming families. In the Guinea Savannah food provisioning lasted from three months to up to one year as responded by the farming families. It could be deduced that both the Sahel and Sudan Savannah grain production last between 3 to 6 months while the Northern Guinea Savannah appeared stable in family food provisioning.

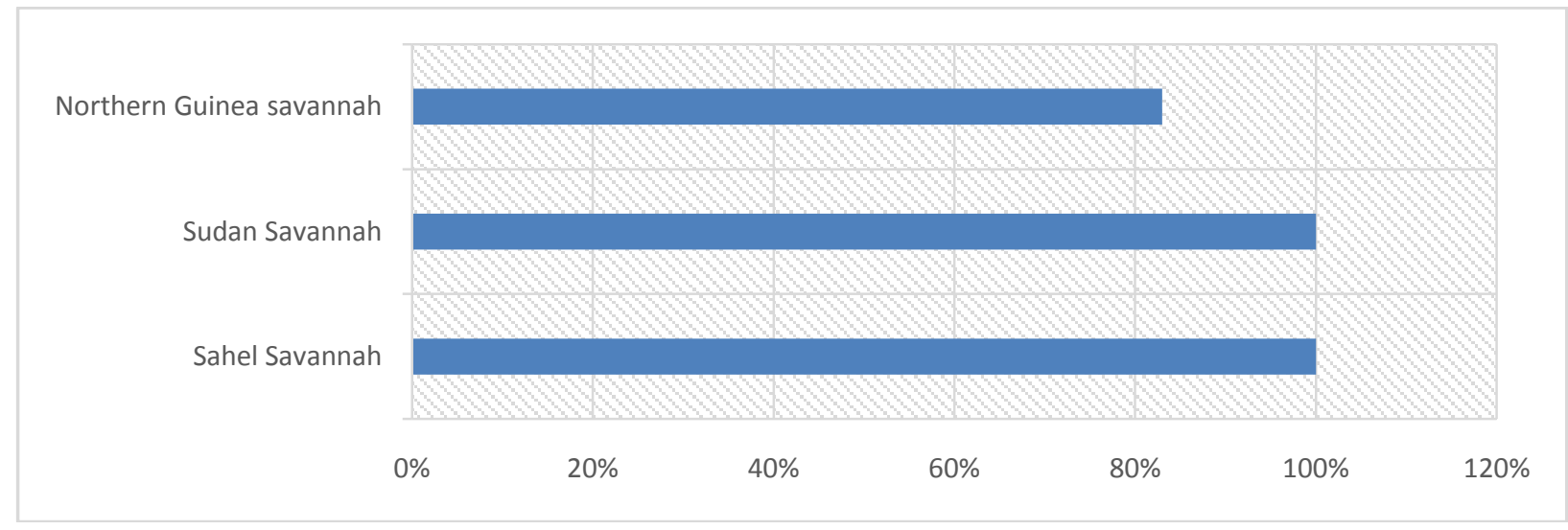

Figure 6 Crop yield decline per agro-ecological zone Source: Field Survey (2015)

In anobservation on farmland conditions, all the key informants were of the consensus that farmlands have so far degenerated over time as the produce continued to decline year after year, affecting the income of the farming families. The key informants buttressed the responses of the farming families.Further, logistic regression was performed to ascertain the effect of the change in the types of crops cultivated, the value of crop production per household and how long household food production lasts on changes in crop yield. 
The model was statistically significant, and the correlation matrix shows the linearity of the association. The Omnibus Tests of Model Coefficients shows the Chi-square values at df 3 to be 129.718 showing a significant relationship between the dependent and the independent variables (Table 4).

Table 4 Omnibus Tests of Model Coefficients

\begin{tabular}{|ll|l|l|l|}
\hline & & Chi-square & df & Sig. \\
\hline \multirow{3}{*}{ Step 1 } & Step & 129.718 & 3 & .000 \\
& Block & 129.718 & 3 & .000 \\
& Model & 129.718 & 3 & .000 \\
\hline
\end{tabular}

Source: Field Survey (2015)

Also, the regression model explains $67.9 \%$ (Nagelkerke $\mathrm{R}^{2}$ ) of the variance in the crop yields and correctly classified $94 \%$ of the variance in crop yields in the study area from the independent variables as shown in Table 5. The change in crops cultivated and crop production per household are more likely to predict the crop yields than the duration of household food.

Table 5 Model Summary

\begin{tabular}{|l|l|l|l|l|}
\hline Step & -2 Log likelihood & $\begin{array}{l}\text { Cox \& Snell R R } \\
\text { Square }\end{array}$ & $\begin{array}{l}\text { Nagelkerke } \\
\text { Square }\end{array}$ \\
\hline 1 & $81.004^{\mathrm{a}}$ & .286 & .679 \\
\hline
\end{tabular}

a. Estimation terminated at iteration number 20 because maximum iterations has been reached.

Source: Field Survey (2015)

\section{Conflict over natural resources use and desertification}

Conflict over grazing lands was used as a measure of the consequences of desertification to which respondents affirmed to its occurrence $(81.0 \%)$ while only $19 \%$ responded "no" to its occurrence as shown in Figure 7 . The respondents' further attest to the occurrence of conflict as a result of farm encroachment into cattle routes while only $35.1 \%$ noticed no such encroachment.

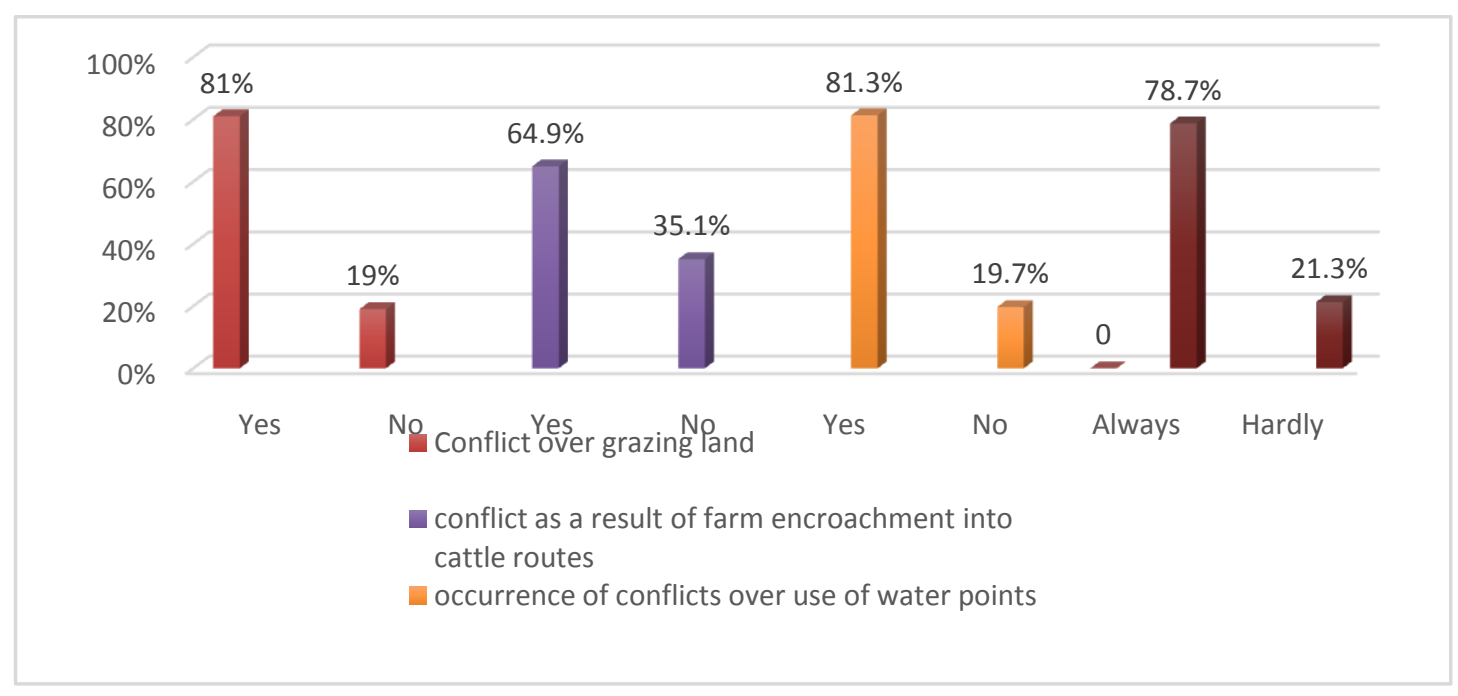

Figure 7 Amplification of conflict over natural resource use

Source: Field Survey (2015)

Most of the conflicts in the study area were precipitated by cattle herders and the farming families either over water points or cattle route annexation or both.On conflicts over the use of water points, $81.3 \%$ of the respondent indicated that there has been an occurrence of such conflict at a frequency of $78.7 \%$ ((Always and sometimes). Only $21.3 \%$ noted that hardly does conflict over natural resource use occurs in the study area. 
Conflicts principally arise when grazing lands are annexed by the farming families. The frequency of the occurrences of such conflicts continues to increase over the years as the Fulani herders try to use the water points, the same point used by the majority of the farming families. Conflicts become further exacerbated when the Fulani have no alternative to feeding their livestock but to release their herds to graze in farmlands particularly after the seedlings have emerged. It could be adduced that the underlying reason for the occurrence of the conflicts stems from the attitudes of both the farming families and the Fulani herdsmen of intolerance.Further, the disaggregated responses from the agro-ecological zones indicated that conflict over grazing land was more rampant in the Sahel and the Sudan Savannah. However, the farming families' responses (68.2\%) from the Northern Guinea Savannah indicated the occurrence of conflict over grazing land in the region was lower as shown in Figure 8.

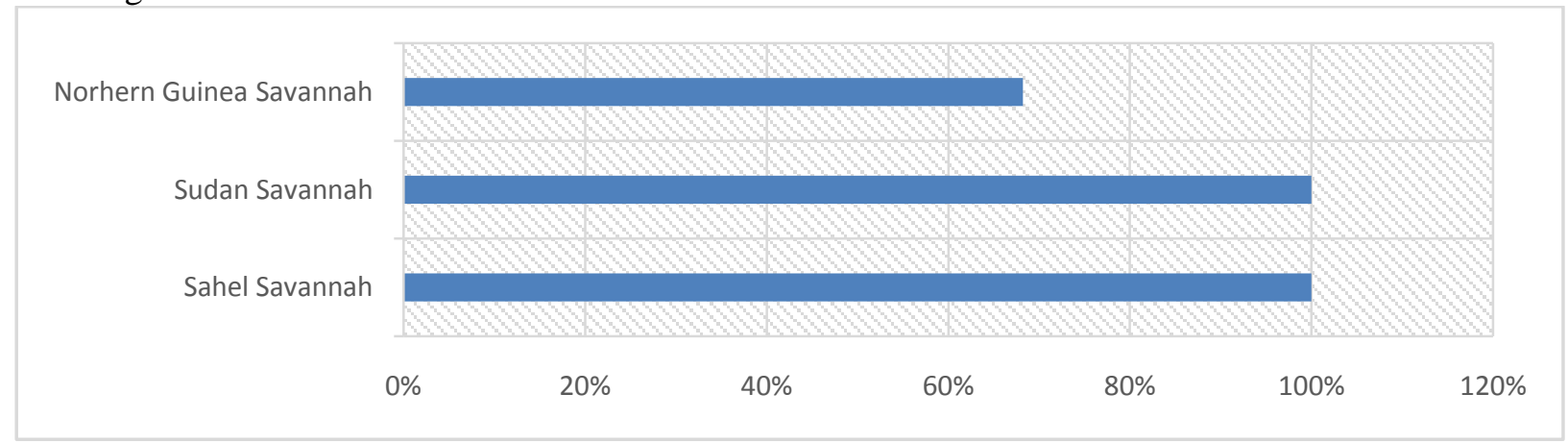

Figure 8 Conflict over grazing lands by ecological zones

Source: Field Survey (2015)

On the conflict over natural resource use, the regression model was further applied to ascertain the effect of farm encroachment into cattle routes and the use of water points on the likelihood of conflict over grazing lands. The correlation matrix shows a linear relationship between the dependent and the independent variables. Further, the omnibus test of the model shows $\chi^{2}(2)=348.684$ with a statistically significant association between the variables as indicated on Table 6.

Table 6 Omnibus Test of Model Coefficients

\begin{tabular}{|ll|l|l|l|}
\hline & & Chi-square & df & Sig. \\
\hline \multirow{3}{*}{ Step 1 } & Step & 348.684 & 2 & .000 \\
& Block & 348.684 & 2 & .000 \\
& Model & 348.684 & 2 & .000 \\
\hline
\end{tabular}

Source: Field Survey (2015)

The model explained $95.9 \%$ (Nagelkerke $\mathrm{R}^{2}$ ) of the variance in conflict over grazing land and can be correctly predicted by $99.2 \%$ from the independent variables as indicated in Table 7 . Water points usage and cattle routes were more likely to predict the dispute over the resource.

Table 7 Model Summary

\begin{tabular}{|c|c|c|c|}
\hline Step & -2 Log likelihood & \begin{tabular}{|l|l} 
Cox \& Snell \\
Square
\end{tabular} & \begin{tabular}{l|l}
$\mathrm{R}$ & $\begin{array}{l}\text { Nagelkerke } \\
\text { Square }\end{array}$ \\
\end{tabular} \\
\hline 11 & $25.273^{\mathrm{a}}$ & .596 & .959 \\
\hline
\end{tabular}

a. Estimation terminated at iteration number 20 because maximum iterations has been reached

Source: Field Survey (2015)

Also, a cross tabulation was performed between change in crop yields and occurrence of conflict over grazing lands. The results indicated the Pearson Chi-square value as 139.055, the degree of freedom indicated 1; the linear-by-linear association is 138.693 as indicated in Table 8. The significance (2-sided) was .000. The Chisquare being greater in value shows the existence of a relationship between the variables. 
A further check on the symmetric measures indicated that the Phi and Cramer's values were both .601 at a significance of .000 . The result shows a positive relationship between the variables.

Table 8 Cross Tabulation

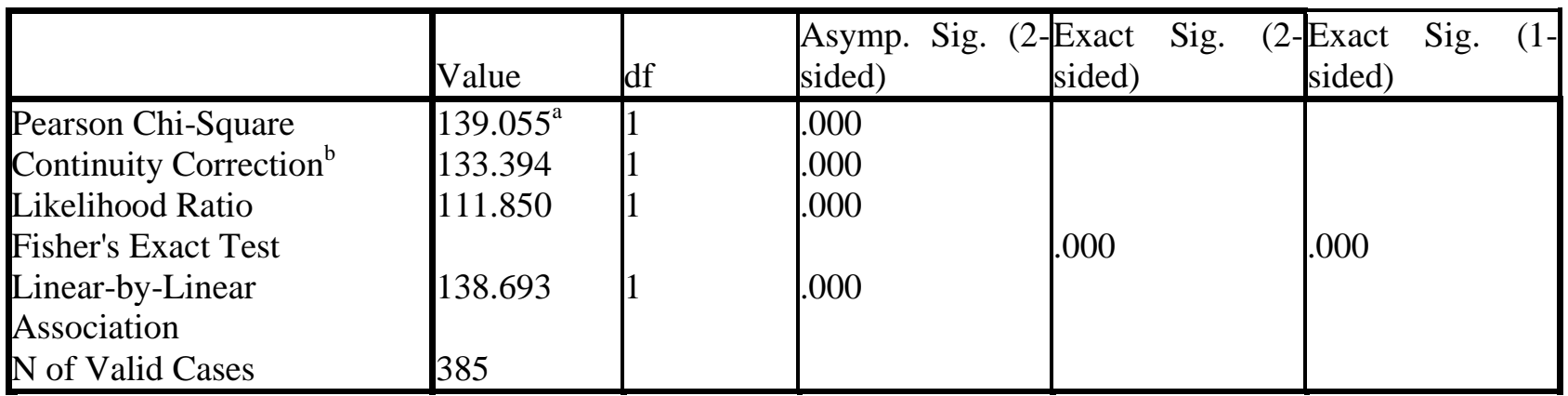

a. 0 cells $(.0 \%)$ have expected count less than 5. The minimum expected count is 5.69.

b. Computed only for a $2 \times 2$ table

Source: Field Survey (2015)

\section{Migration and desertification}

The survey indicated that about $77 \%$ of the farming families were of the opinion that people did seek livelihoods in the urban centres whereas only $18 \%$ of the respondents indicated people migrated to other countries. Conversely, only $23 \%$ of the respondents indicated no migration to cities and $81.8 \%$ were of the opinion that people did not immigrate to other countries. The result further revealed that only $18 \%$ of the responses indicated that both migration and immigration have affected the traditional knowledge of land conservation. $81.8 \%$ responded that there had been no loss of traditional knowledge as shown in Figure 9.

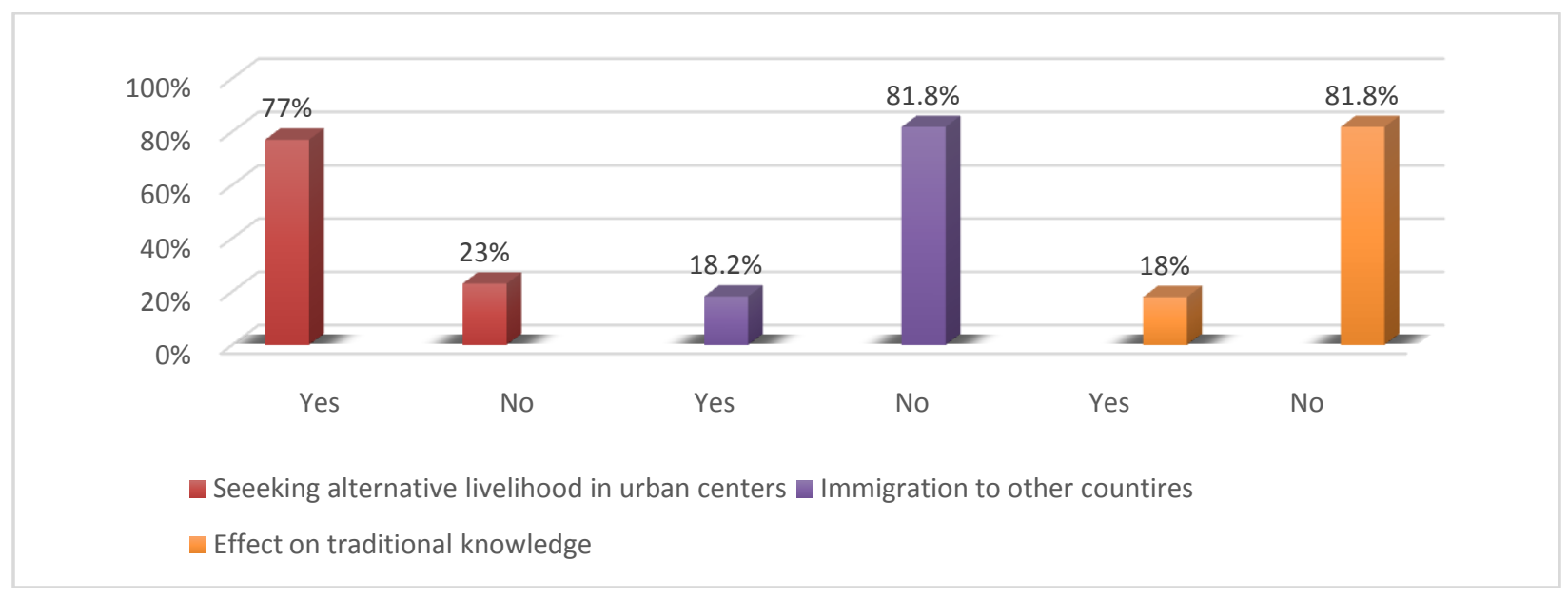

Figure 9 Extent of desertification induced migration Source: Field Survey (2015)

UNESCO (2007) noted that ecological emigration finally is a very clear human sign of the loss of the productive potential of the land. At the agro-ecological fronts, the responses indicated that $92.1 \%$ of the farming families in the Sahel region affirmed that people migrated to urban cities to seek alternative livelihoods. The aggregate score from the Sudan Savannah indicated $87.9 \%$ of the farming families in affirmation of the migration incidences. However, a slight decline was recorded in the Northern Guinea Savannah where $73.5 \%$ of the farming families noted the frequency of migration to urban centres. This result indicates that much of the migration in the study area was more common in the Sahel region followed by the Sudan savannah as shown in Figure 10. The general view indicates that indeed people migrated most often to urban-centres symptomatic of the urgency to augment the income of the farming families occasioned by the declining yields of the farmlands. 


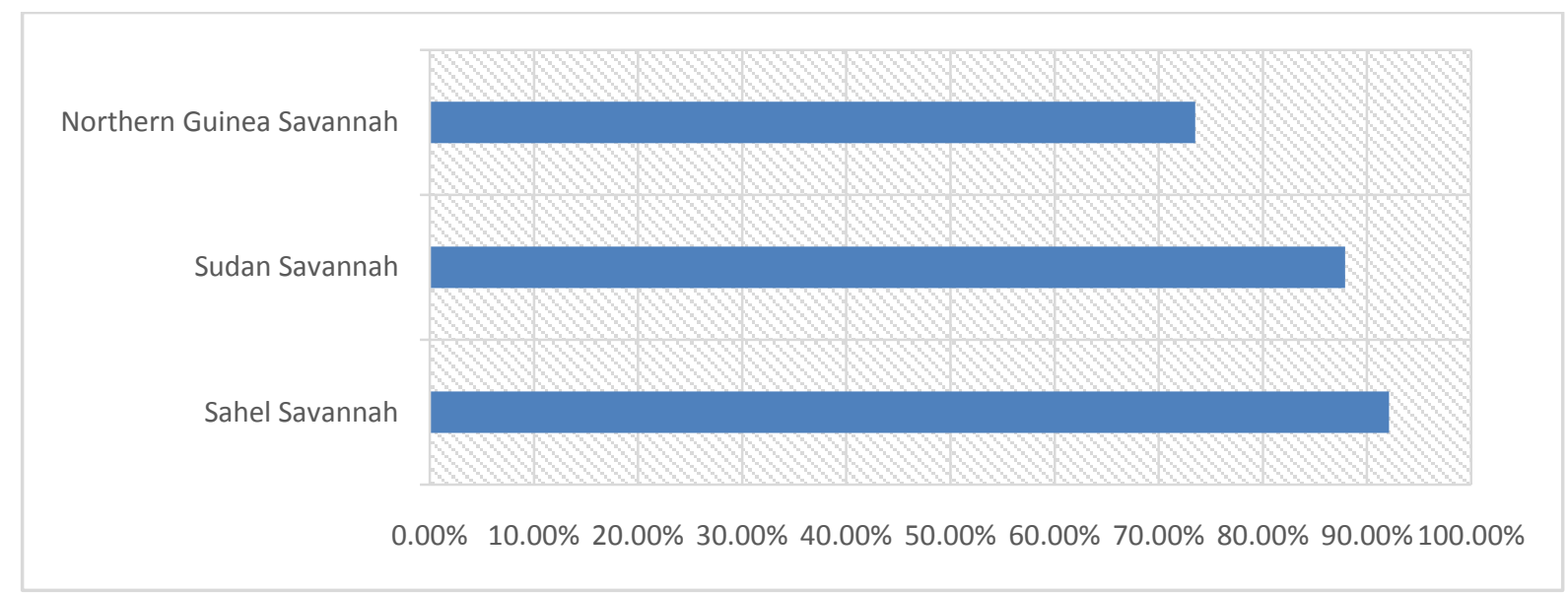

Figure 10 Migration trends from agroecological zones

Source: Field Survey (2015)

According to akey informant, the agricultural sector is suffering because most of the youth always go for ChiRani (Migration for off-farm activities) and most of them do not come back early for pre-planting activities. The produce continued to decline, and cultivable areas are decreasing because of this manpower shortage and erosion. The results mirrored the findings of rural livelihood in Gursulu village, Yobe State as described by Gbahago (2011) and the findings of Olagunju (2015) who reveals that a major consequence of desertification in Nigeria is migration which causes separation of families as men usually abandon the women and children to seek employment in the urban centres due to unproductive agricultural practice in the rural areas. Also, Abdi et. al. (2013) and Ababa (2007) attribute the impact of desertification to include migration precipitated by declining yields.

Similarly, regression was performed to ascertain the effects of people seeking alternative livelihoods in urban centres and people immigrating to other countries on crop yields. The correlation matrix indicated the existence of a linear relationship between the dependent and the independent variables. Likewise, the greater the chi-square statistic, the stronger the relationship between the independent and dependent variable. In which case the Omnibus Test of Model Coefficients shows a significant association and a $\chi^{2}(2)=96.966$ as shown in Table 9.

Table 9 Omnibus Test of Model Coefficients

\begin{tabular}{|ll|l|l|l|}
\hline & & Chi-square & df & Sig. \\
\hline \multirow{3}{*}{ Step 1 } & Step & 96.966 & 2 & .000 \\
& Block & 96.966 & 2 & .000 \\
& Model & 96.966 & 2 & .000 \\
\hline
\end{tabular}

Source: Field Survey (2015)

The model summary explained Nagelkerke $\mathrm{R}^{2}$ as .528 , indicative of $52.8 \%$ contribution in crop yield decline in the study area. It further correctly predicted urban migration to be more contributory to explain crop yield decline than immigration to other countries(Table 10).

Table 10 Model Summary

\begin{tabular}{|l|l|l|l|}
\hline Step & 2 Log likelihood & $\begin{array}{l}\text { Cox \& Snell R Nagelkerke R Square } \\
\text { Square }\end{array}$ & \\
\hline 1 & $113.756^{\mathrm{a}}$ & .223 & .528 \\
\hline
\end{tabular}

a. Estimation terminated at iteration number 20 because maximum iterations has been reached. Source: Field Survey (2015)

Again, a cross tabulation was applied between change in crop yields with people seeking an alternative livelihood in the urban centres. The result indicated the Pearson Chi-square value at 108.207, with 1 degree of freedom, and linear-by-linear association of 107.926 at a significance (2-sided) of .000 . 
The Phi and Cramer's V further showed each at a value of .530 at a relative significance of .000. This result indicates a positive relationship between the variables.

Table 11 Chi-Square Test

\begin{tabular}{|c|c|c|c|c|c|}
\hline & Value & df & $\begin{array}{l}\text { Asymp. } \\
\text { (2-sided) }\end{array}$ & Sig. $\begin{array}{l}\text { Exact Sig. } \\
\text { sided) }\end{array}$ & $\begin{array}{l}\left(2-\begin{array}{l}\text { Exact Sig. (1- } \\
\text { sided })\end{array}\right. \\
\end{array}$ \\
\hline Pearson Chi-Square & $108.207^{\mathrm{a}}$ & 1 & .000 & \multirow{8}{*}{.000} & \multirow{8}{*}{.000} \\
\hline Continuity & 103.566 & 1 & .000 & & \\
\hline Correction $^{\mathrm{b}}$ & & & & & \\
\hline Likelihood Ratio & 96.966 & 1 & .000 & & \\
\hline Fisher's Exact Test & & & & & \\
\hline Linear-by-Linear & 107.926 & 1 & .000 & & \\
\hline $\begin{array}{l}\text { Association } \\
\mathrm{N} \text { of Valid Cases }\end{array}$ & 385 & & & & \\
\hline & & & & & \\
\hline
\end{tabular}

a. 0 cells $(.0 \%)$ have expected count less than 5. The minimum expected count is 6.94 .

b. Computed only for a $2 \times 2$ table

Source: Field Survey (2015)

\section{Losses of farmlands and desertification}

The responses to the increase or decrease in the number of farm lands by the farming families indicated that $62.9 \%$ were of the view that there was an increase while $37 \%$ indicated there was no increase in the number of farmlands. Besides, $72.2 \%$ noted that there were eroded lands in their areas while $27.7 \%$ have not noticed any eroded land in their areas as shown in Figure 11. The finding runs contrary to widely held beliefs which identified abandoned farmland as an economic manifestation of desertification (e. g. Squires, 2006).

\section{Abandoned settlements and desertification}

The survey further revealed there are no abandoned settlements as responded by $94.5 \%$ of the farming families. Similarly, only $85.7 \%$ could not attribute rainfall factor as a reason for some people to leave their settlements. The survey revealed that very few areas have barren land (14.3\%). The non-siting of abandoned settlement could be because of the traditional tenure system in the study area, where land is seen as a heritage and passed on from one generation to the other and further as a symbol of the social ranking of individuals (Figure 11).

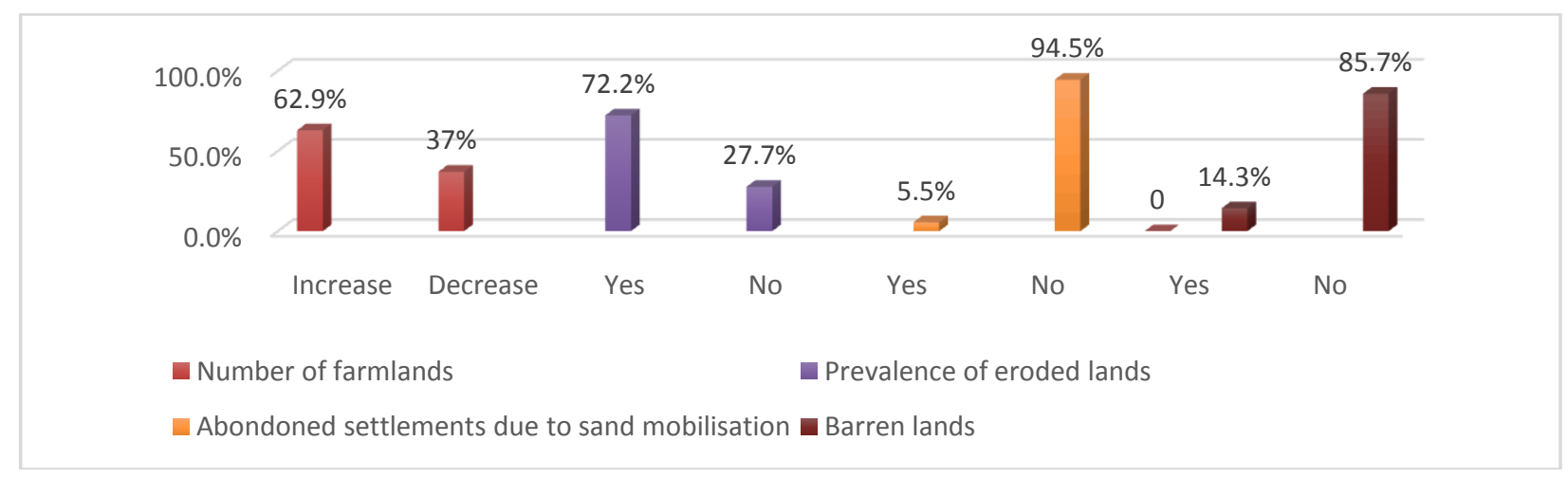

Figure 11 Desertification induced loss of farmland and abandoned settlement Source: Field Survey (2015)

The findings agree with the argument of Rozin \& Wolf (2008) that land may also be considered part of a person's extended self, and hence have a particular relation to the individual. In Kunert's (2012) findings, evidence suggests that farmers often have a strong attachment to their farmland and wanted their children to continue to farm on their land, and not other people's land. He argued that individuals in rural areas have been found to develop place attachment. The assertion captures the situation of the settlement and farmlands in Unguwar Jummai (Figure 12 \& 13) 


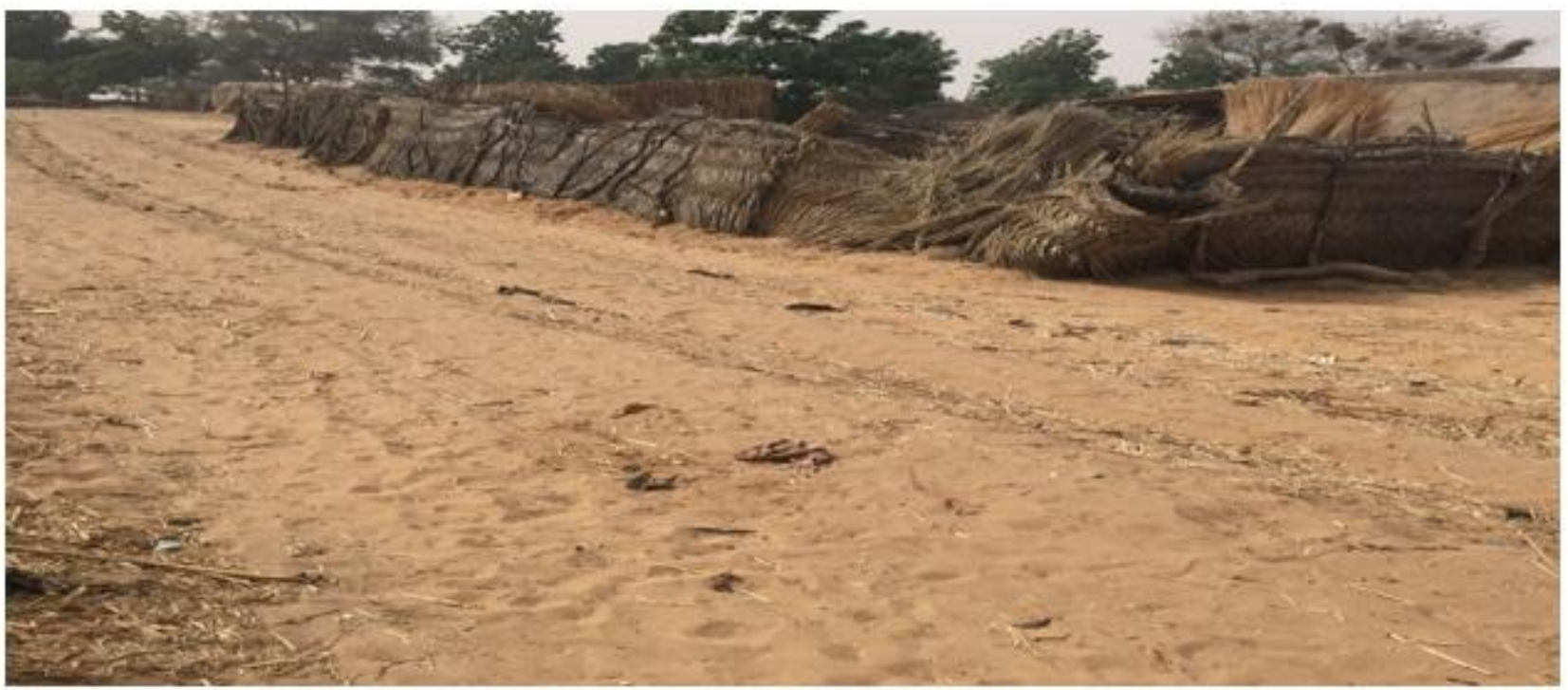

Figure 12 Sand movement threatening a settlement (UnguwarJummai) Source: Field Survey(2015)

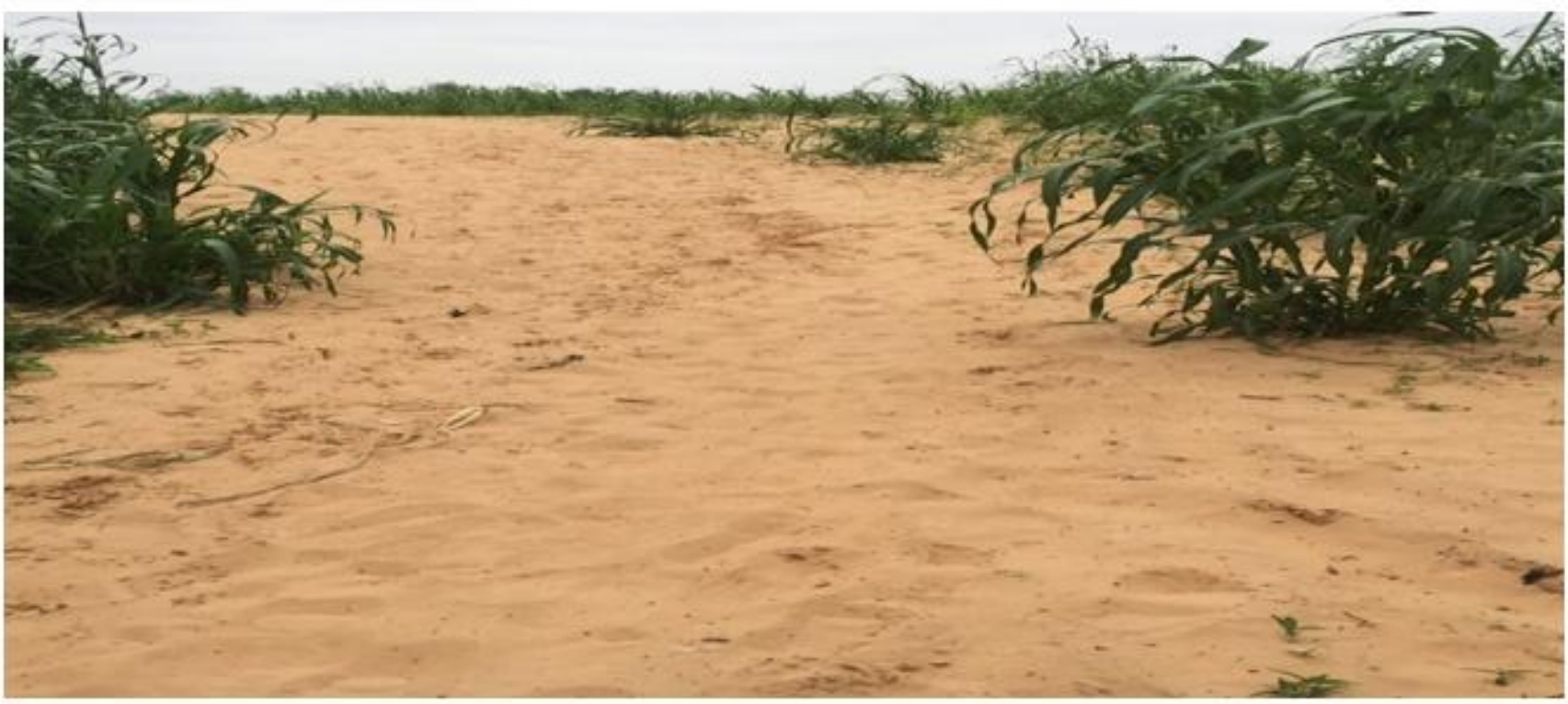

Figure 13 Sand movement into farmlands (UnguwarJummai) Source: Field Survey(2015)

\section{Dried up wells and desertification}

The respondents (26.4\%) indicated that there are few cases of dried wells in their area, but $75.5 \%$ were of the opinion that there were no cases of dried wells in their area. Similarly, only $37.6 \%$ were aware of abandoned wells in the neighbourhood while $62.4 \%$ were unaware of any abandoned wells in their neighbourhood. Dredging of the wells which show a decrease in aquifer flow rate has become a part of the annual routine that the farming families perceived as a secure way to ensure a continuous supply of water. The farming families opined that abandoned wells were seen as a result of non-dredging by the farming families.

\section{Forest Reserve and desertification}

Only $25.7 \%$ of the respondents indicated they have forest reserves while $74.3 \%$ reported that they do not have a forest reserve as shown in Figure 14. The responses further showed that people engaged in deforestation (79\%) while some respondents $(21 \%)$ opined that there was no deforestation in their area. Interestingly, forest reserves were converted to farmlands according to the respondents $(78.2 \%)$, while $21.8 \%$ did not hold to such perception. 
The non-sighting of the forest reserve could be explained by the rate of deforestation in the study area as a result of high incidence of poverty that resulted from the declining farm yields and reduced family income. The disaggregated responses from the agro-ecological zones indicated that deforestation hub in the study was the Sahel and the Sudan Savannah as confirmed by the farming families in the respective zones. Only $45 \%$ of the farming families in the Northern Guinea Savannah testified to the practice of deforestation in the zone. Thelma (2015) observed that many people are faced with the problem of high cost of kerosene and cooking gas, thereby leaving individuals with no option than deforestation to provide fuel wood for the majority of the populace. In a study of the underlying causes of forest decline, Contreras-Hermosilla (2000) argued that forest degradation is, in varying degrees, economically wasteful and environmentally negative, as well as socially undesirable.

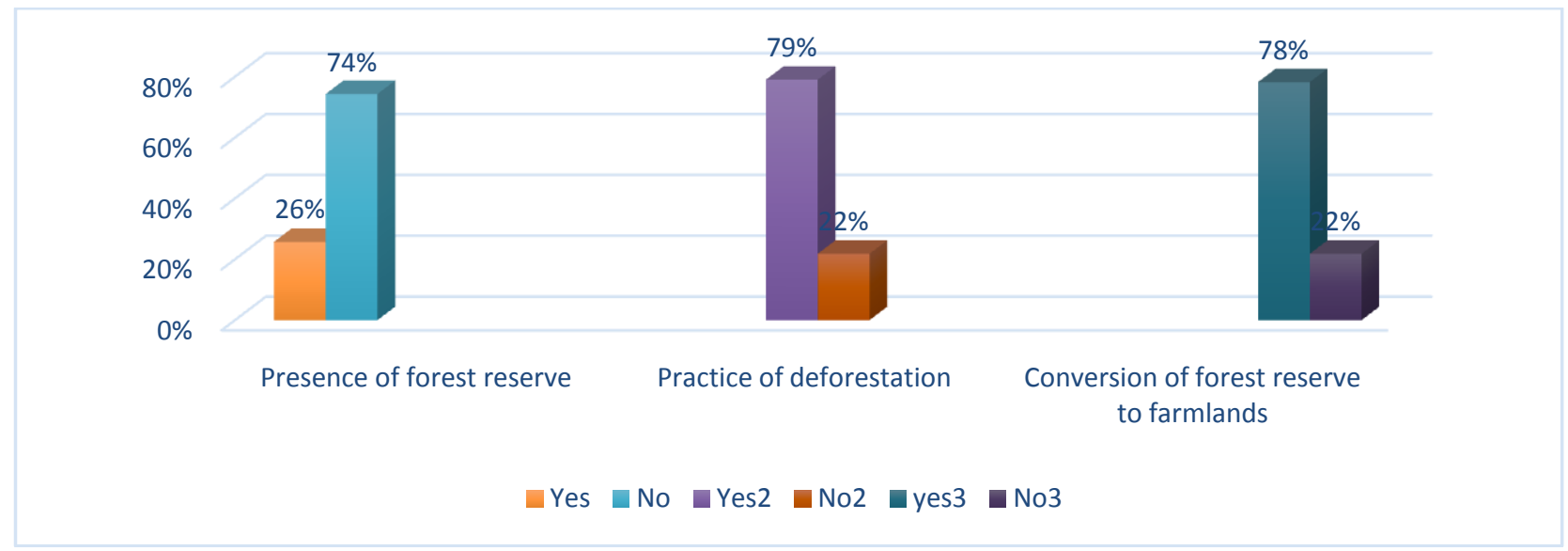

Figure 14 Forest reserve condition due to desertification

Source: Field Survey (2015)

According to one key informant the problem of forest reserves is most unfortunate as much of the efforts of the forefathers seem to have gone in vain. The main culprits in forest reserve degradation and destruction were those in power. In a bid to increase personal land or increase the size of farmlands forest reserves were allocated either consciously or otherwise to the influential persons. Furthermore, according to the key informant"it seems the Government does not take environmental issues seriously as we are living witness to the complete destruction of the Kabakawa forest and the Katsina City wall plantation. Some of the reserves in other areas were dreadfully annexed by individuals of course with the connivance of Local Authorities. The loss of forest in our area calls for concern. The situation is so bad that medicinal plants like Dorawa (Parkiabiglobosa), Gawasa (Parinarimacrophylla), Katsari (Abizziachevalieri) and Kirya (Proposis Africana) have become difficult to find. Our communities are now seeing the effect of the continued felling of these trees". The sentiments and concerns expressed by the key informant seem to agree with other impressions noted by Saulawa (1992), Ababa (2007) Abdi et.al.(2013) and Hussaini (2014).

The study also explored forest reserve availability with the logistic regression. The result of the regression indicated a linear relationship between the variables (deforestation, conversion of forest reserves to farmland and conditions of the grazing lands)

Table 12 Correlation Matrix

\begin{tabular}{|ll|l|l|l|l|}
\hline & & Constant & Engaged & Converted & Grazing \\
\hline \multirow{4}{*}{ Step 1 } & Constant & 1.000 & -.157 & -.141 & .560 \\
& Engaged & -.157 & 1.000 & -.950 & .000 \\
& Converted & -.141 & -.950 & 1.000 & -.252 \\
& & & & & \\
& Grazing & .560 & .000 & -.252 & 1.000 \\
\hline
\end{tabular}

Source: Field Survey (2015) 
The data also showed a normal distribution and a statistically significant relation $\left(\chi^{2}(3)=216.842\right)$. The Chisquare, which is associated with .05 probability, shows a significant relationship between the dependent and independent variables(Table 13).

Table 13 Omnibus Test of Model Coefficients

\begin{tabular}{|ll|l|l|l|}
\hline & & Chi-square & df & Sig. \\
\hline \multirow{3}{*}{ Step 1 } & Step & 216.842 & 3 & .000 \\
& Block & 216.842 & 3 & .000 \\
& Model & 216.842 & 3 & .000 \\
\hline
\end{tabular}

Source: Field Survey (2015)

The model explained that the Nagelkerke $\mathrm{R}^{2}$ as.633, thus explaining the $63.3 \%$ of the variance in forest reserve availability in the study area. Further the results indicated that the condition of the grazing land and deforestation have a higher likelihood to influence forest reserve availability. Similarly, a cross tabulation was employed between change in crop yields with deforestation, and a significant relationship was observed between the variables. The Chi-Square Test revealed a value of 122.107 at a degree of freedom of 1 . The linear -by-linear association was 121.790 while the significance (2-sided) was .000 indicating a strong relationship between the variables.

Table 14 Chi-Square Tests

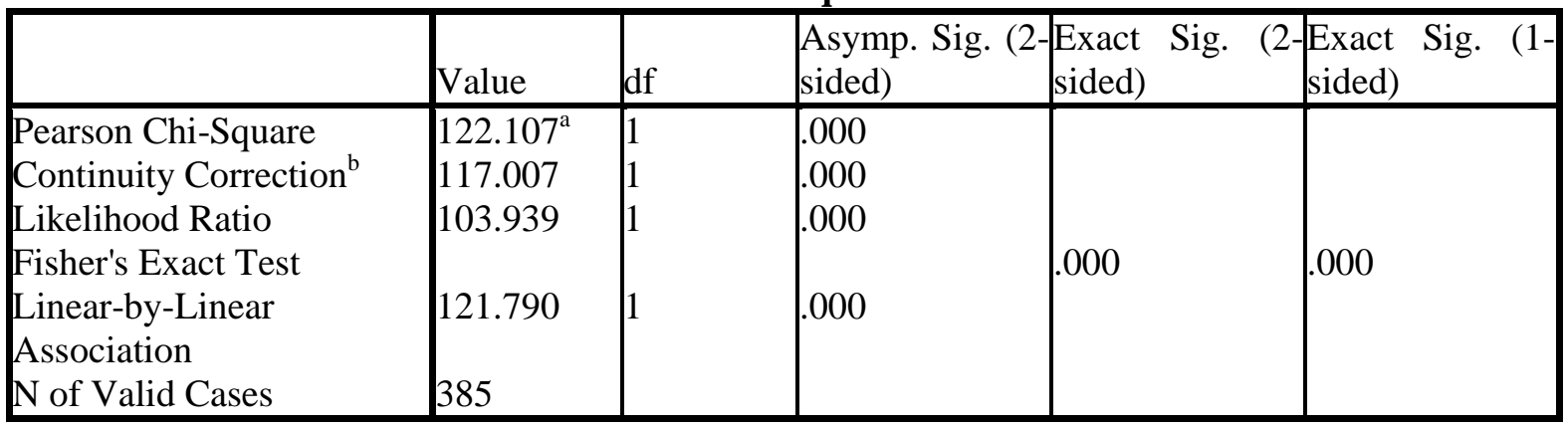

a. 0 cells $(.0 \%)$ have expected count less than 5 . The minimum expected count is 6.31 .

b. Computed only for a $2 \times 2$ table

Source: Field Survey (2015)

\section{Grazing lands and desertification}

The survey indicated that $42.8 \%$ of the respondents perceived the current situation of the grazing areas to be in a poor state due to bush encroachment. That $31.2 \%$ was due to decline in palatable species and $26 \%$ overgrazing; leading to bare surfaces. The respondents $(77.1 \%)$ were also of the view that the number of grazing lands was not adequate while about $23 \%$ have adequate grazing lands in their area (Figure 15). The inadequacy stems from the fact that pastoral lands were being annexed and converted into farmlands by farming families. A similar condition of grazing lands was also reported by Darkoh (1996) who observed that the rangelands in eastern and southern Africa were fast disappearing. Population pressures in rainfed croplands, and the increasing encroachment of cultivators on adjacent rangelands were diminishing the areas of available grazing, thus intensifying overstocking and overgrazing. 


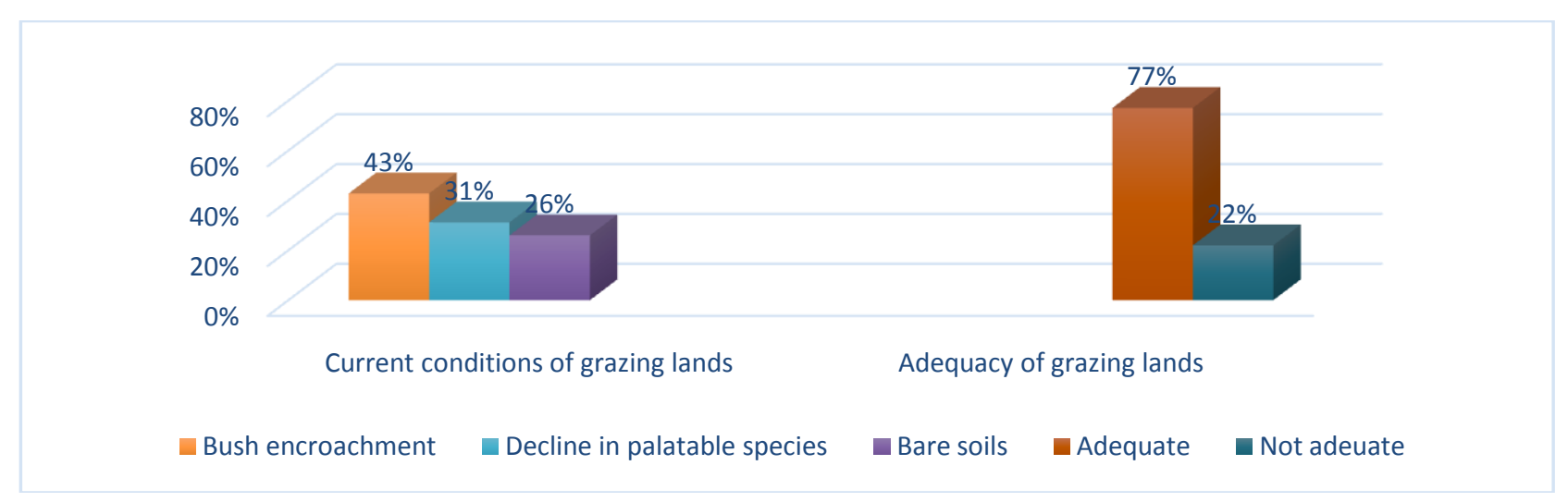

Figure 15 Pastoral land conditions

Source: Field Survey (2015)

In a similar postulation on grazing lands, one key informant opined that the issue of pastoral lands is analogous to the annexation of forest reserve. Farmlands close to the grazing lands were gradually increased in size by farming families, adding additional meters of the grazing lands into cultivation. The process starts with three to four ridges and after years of this encroachment, a small area will be left as a grazing land. In addition, the condition of the remaining grazing land continues to deteriorate and there is nothing done to ameliorate the situation. Grazing is now every man for himself. The results appear consistent with the findings of studies carried out by Ijah (2014) and Okelloet. al. (2014).

The Phi and Cramer's V further showed each at a value of .530 at a relative significance of .000 . This result indicates a positive relationship between the variables as shown in Table 15.

Table 15 Symmetric Measures

\begin{tabular}{|ll|l|l|}
\hline & & Value & Approx. Sig. \\
\hline Nominal by Nominal & Phi & .563 & .000 \\
& Cramer's V & .563 & .000 \\
N of Valid Cases & & 385 & \\
\hline
\end{tabular}

\section{Conclusions and Recommendations}

Source: Field Survey (2015)

The paper has attempted to identify the impact of desertification on livelihoods in Katsina State, with the aim of contributing to literature as well as providing an empirical viewpoint to the policymakers in their bid to package policies to deal with the desertification impact in the State. The study of the impacts of desertification on livelihoods indicates an overlap and interaction between various socio-economic indicators.The study further established that the impact of desertification on livelihoods in the study area includes a negative effect on pastoralism, decline in crop yields and amplification of conflict between the farming families and the Fulani herders. Desertification was further revealed to have influenced migration to urban centres and accelerated outmigration to other countries, as well as diminishes forest reserves. As a result of desertification, grazing lands observed during the fieldwork were found in several places to be in a poor state, interspersed in most cases with bush and bare surfaces and highly conspicuous absence or disappearance of palatable species. Contrary to the generalized views, the loss of farmland, abandoned settlements and dried up wells in the area were not common; as a result, desertification could not be meaningfully assessed regarding their impacts in the study area. The result of this study concretizes the central statement of the study that impact of desertification is site-specific, and each location requires its independent analysis before a conclusion could be reached.

It is recommended that due to the prevalence of poverty in the study area, there is the need for more empowerment and diversification of employment opportunities. The State Government should initiate a redemarcation exercise of the cattle routes and legislate on the use and distinctiveness of the demarcated routes. The State Government should consult with and involve communities in reforestation and conservation measures. 


\section{Conflict of interest}

The authors have not declared any conflict of interests.

\section{References}

Ababa, A. (2007). Africa Review Report on Drought and Desertification. Fifth Meeting of the Africa Committee on Sustainable Development. Regional Implementation Meeting for CSD-16, 8-14.

Abbas, I.M. (2014). No Retreat No Surrender Conflict on Survival Between Fulani Pastoralist and Farmers in Northern Nigeria. European Scientific Journal 8 (1), 331-346.

Abdi, O. A., Glover, E.K. \&Luukkanen, O. (2013). Causes and Impacts of Land Degradation and Desertification: Case study of the Sudan. International Journal of Agriculture and Forestry 3 (2), 40-51.

Adekunle, V.A. (2009). Contribution of Agroforestry Practice in Ondo State Nigeria to Environmental Sustainable Agricultural Production. Africa Focus 22 (2),27-40.

Adekunle, A. A., lowo A. T. \&Alade A. A.(2005).Bridging the Communication Gap Between Scientist and Farmers in Katsina State Nigeria. International Institute of Tropical Agriculture (IITA) Ibadan, Nigeria, 2-

Baartman, J. E.M., van Lynden, Reed, M.W.J., Ritsema, S., Coen, J. \& Hessel, R. (2007) Desertification and Land degradation: Origins, Processes and Solutions. Report Number 4. ISRIC Netherlands.

Butterworth, R., Saghir, P.A. \&Martin, A. (2008). Cassava-Adding Value to Africa. Gender and Diversity ReportNigeria, Abeokuta:Natural Resource Institute.

Chambers, R \& Conway, G. R. (1992). Sustainable Rural Livelihoods. Practical concepts for the $21^{\text {st }}$ century. Discussion paper 296. Brighton: Institute of Development Studies.

Contrrras-Hermosill, A (2000). The Underline Causes of Forest Decline. Occasional Paper No. 30. Center for International Forestry Research, Indonesia.

Darkoh, M.B.K (1996a). The Human Dimensions of Desertification in the Drylands of Africa.Journal of Social Development in Africa 11(2), 89-106.

Darkoh M.B.K. (1998) The Nature, Causes and consequences of Desertification in the dry lands of Africa. Land and Development 9, 1-20.

Dregne, H.E. (1996). Desertification: Challenges ahead. Ann. Arid Zone 35:305-311.

El-Karouri, M.O.H. (1986). Impact of desertification on Land Productivity, In Farouk E.\&Hassan, M.H. Eds.(pp52-59), A Physics of Desertification. Dordrecht, The Netherlands:MartinusNijhoff Publishers.

Ellis, F (1998). Household Strategies and Rural livelihood diversification. Journal of Development Studies 35(1), 1-38.

Ellis, F (1999). Rural Livelihood Diversity in Developing Countries: Evidence and Policy Implications. Natural Resource Perspective 40, London: Overseas Development Institute.

Emeka, E.E. (2013). Drought and Desertification as they affect the Nigerian Environment. Journal of Environmental Management and Safety 4 (1), 45-54.

FAO (1983). Provisional methodology for assessment and mapping of desertification. Food and Agriculture Organization of the United Nations. Global Environmental Monitoring System. Rome: FAO.

FAO (1993). Sustainable development of drylands and combating desertification. Corporate Document Repository, Rome: FAO.

FAO (2001). Food insecurity-When People live with Hunger and Fear Starvation-UN Food and Agricultural Organization, Rome: FAO

FGN (2012). Great Green Wall for the Sahara and Sahel Initiative. National Strategic Action Plan. Federal Ministry of Environment of Nigeria.

Foster D., Swanson, F., Aber J., Brake, I., Brokow, N., Tilman, D. \& Knapp Alan. (2003). The importance of land-use legacies to ecology and conservation. Bioscience 53, 77-89.

Fredricson E., Havstard K.M \&Hyder R. (1998). Perspective on desertification. South-Eastern United States. J. Arid Environment 39,191-207.

Grainger, A. (2009). The threatening Desert. Controlling Desertification. International Institutefor Environment and Development. IIED

Gbahabo, T. P (2011). Desertification and rural livelihoods. The case of Gursulu village, Yobe State Nigeria. A research report submitted to the Faculty of Humanities, University of Witwatersrand Johannesburg in partial fulfilment for the requirement for the degree of Masters of Arts. 
Hussaini, M.U (2014). The Impact of Economic Activities on Deforestation in Bauchi State.(A Theoretical Perspective). IOSR Journal of Humanities and Social Science 19(3), 14-18.

Ibrahim, S. S \&Aliero, H. M. (2012). Analysis of farmers' access to formal credit in the rural areas of Nigeria. African Journal of Agricultural Research 7(47), 6249-6253.

Ijah, A (2014). Conflicts between Fulani Herders and Farmers in Central and Southern Nigeria: Discourse on proposed establishment of grazing routes and reserves. AnInternational Journal of Arts and Humanities3(9), 66-84.

Kasas, M. (1995). Desertification: a general review. J. Arid Environment 30, 115-128.

Krejcie\& Morgan (1970) "Determining Sample Size for Research Activities". Educational and Psychological Measurement \#30, 607-610.

Kristensen, P (2004). The DPSIR framework. Paper presented at the 27-29 ${ }^{\text {th }}$ Sept. Workshop oncomprehensive/detailed assessment of vulnerability of water resources to environmental change in Africa using River Basin Approach. Nairobi: National Environmental Research Institute, UNEP Headquarters.

Le Houerou, H. N. (1996). Climate Change, Drought and Desertification. Journal of Arid Environment 34,133185.

Loxton, E., Schirmer, J. \&Kanowski, P. (2014). Social Impacts of Policy Change in Western

Australia on Members of the Natural Forest Industry: Implications for policy goals and decision-making process. Forestry International Journal of Forest Research, 87, 363-376.

MA (2005) Ecosystems and Human Well-being Desertification Synthesis, World Resource Institute, Washington DC.

Maiangwa, M.G., Ogungbile, A.O., Olukosi, J.O.\&Atata, T.K. (2007). Land Degradation: Theory and Evidence from the North-West Zone of Nigeria. Journal of Applied Sciences 7, 785-795.

Mooney, A.K. \&Dakwa, B. K. (2014). Prospects and Potentials of Kakum Conservation Area, Ghana. Journal of Ecology and Natural Environment 6(5), 140-153.

Mortimore, M. (1989). Adapting to Drought. Farmers, Famines and Desertification in West Africa. Cambridge University Press.

Nneji, L.M. (2013). A Review of the Effects of Desertification on Food security. Report and Opinion 5(10), 2733.

Nuhu, H.S, Donye, A.O \&Bawa, D.B. (2014). Barriers to women participation in agricultural development in Bauchi Local Government area of Bauchi State, Nigeria. Agriculture and Biology Journal of North America 5(4), 166-174.

Oladipo E.O. (1993). A Comprehensive Approach to Drought and Desertification in Northern Nigeria. Natural Hazards 8, 235-261.

Okello. A. L, Majekodumi, A.O., Molala, A., Welburn, S.C. \& Smith, J. (2014). Identifying motivators for StatePastoral dialogue: Exploring the relationship between livestock services, self-organization and conflict in Nigeria's Pastoralist Fulani. Pastoralism 4(12), 1-14.

Oladipo E.O. (1993). A Comprehensive Approach to Drought and Desertification in Northern Nigeria. Natural Hazards 8, 235-261.

Olagunju, T. E (2015). Drought, Desertification and the Nigerian Environment: A review. Journal of Ecology and Natural Environment 7, 196-209.

Orr S., Carlwright, A. \&Tickner, D. (2009). Understanding water risks. A primer of the consequences of water scarcity for government and business. WWF Water Security Seriesb4.

Reynolds J.F. \& Smith, D.F. (Ed.) (2001). Global Desertification. Do Human's Cause Deserts? Report of the $88^{\text {th }}$ Dahlem Workshop in Global Desertification.Dahlem University Press.

Rozin, P \& Wolf, S. (2008). Attachment to Land: The Case of the Land of Israel for American and Israel Jews and the Role of Contagion. Judgement and Decision Making, 3 (4), 325- 334.

Saulawa. A.M. (1992). The State Ecological Problems in Katsina. African Arid Lands. Working Paper Series No1/92, 1-12.

Senanayake, R. (2012). Desertification and Biodiversity. Ground Views Journalism for Citizens.http://groundviews.org/?s Accessed on the 30 January, 2015.

Scoones, I. (1998). Sustainable Rural Livelihoods. Framework for analysis Paper 72, Brighton, UK Institute for Development Studies. 
Sokona, Dr. Y. (2007). Combating desertification-The big challenge for the $21^{\text {st }}$ Century. Regional Aspects-SubSaharan Africa. Agriculture and rural development 1, 14-16.

Squires, V. R (2006). Desertification Extent of. In Lal, R. Eds. (456-457). Encyclopaedia of $\quad$ Science. Second Edition, USA: CRS Press.

Stephen, D. (2014). Land Degradation and Agriculture in the Sahel of Africa. Causes, Impacts

And Recommendations. Journal of Agricultural Science and Applications (J.Agric.Sci.Appl.) 3(3), 67-73.

Stiles, D.N. (1983). Desertification and Pastoral Development in Northern Kenya. Commission on Nomadic Peoples. Nomadic Peoples 13, 1-14.

Thelma, M. N. (2015). Desertification in Northern Nigeria: Causes and implication for National food security. Peak Journal of social sciences and Humanities 3(2), 22-31.

Tsue, P.T., Nweze, N.J \& Okoye, C. U. (2014). Effects of Arable Land Tenure and Use on Environmental Sustainability in North Central Nigeria. Journal of Agriculture and Sustainability 6(1), 14-38.

Tully T.G. \& Shapiro, E. (2014). Analysis of Kenyan Livestock Market and Feasibility Study of Livestock Business. Masters project submitted in partial fulfillment for the Master of Environmental Management in the School of the Environment of Duke University.

UNCCD (1994). Elaboration of an International Convention to Combat Desertification in Countries Experiencing Serious Drought and Desertification particularly in Africa.

UNCCD (2013). A Stronger UNCCD for a LAND Degradation Neutral World. Secretariat of the United Nations Convention to Combat Desertification, Bonn, Germany.

UNCCD (2014). Desertification. The Invisible Frontline. Secretariat of the United Nations Convention to Combat Desertification, Bonn, Germany.

UNEP (2012). 21 Issues for the $21^{\text {st }}$ Century. Results of UNEP Foresight Process in Emerging Environment Issues. Nairobi, Kenya.

UNESCO (2007). African Review Report on Drought and Desertification. Fifth Meeting of the African Committee on Sustainable Development 6.

WCED (1997). Our Common Future: Report of the World Commission on Environment and Development WCED, Switzerland.

Woodsong, C (1994). Old farmers, Invisible farmers, Age and Agriculture in Jamaica. Journal ofCross Cultural Gerontology. Netherlands: Kluwer Academic Publishers.

Zaman, S. (1997). Effects of rainfall and grazing on vegetation yield and cover of two arid Rangelands in Kuwait. Environ. Cons 24, 344-350.

Zdruli, P., Marcello, P., Selim, K. \& Angel F. (2010). Land Degradation and Desertification: Assessment, Mitigation and Remediation.London: Springer Dordrecht Heidelberg 